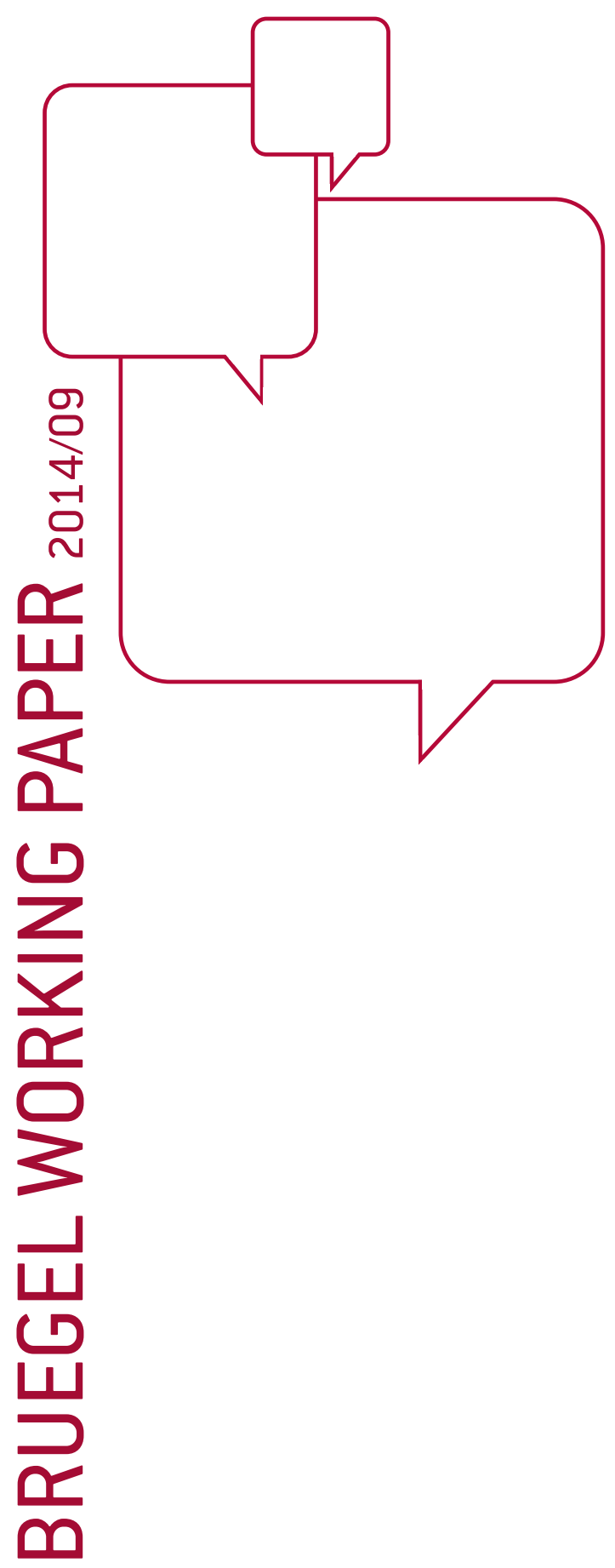

\title{
DID THE GERMAN COURT DO EUROPE A FAVOUR?
}

ASHOKA MODY

Highlights

- The European Central Bank's Outright Monetary Transactions (OMT) programme was a politically-pragmatic tool to diffuse the euro-area crisis. But it did not deal with the fundamental incompleteness of the European monetary union. As such, it blurred the boundary between monetary and fiscal policy. The fuzziness of this boundary helped in the short-term but pushed political and economic risks to the future. Unless a credible commitment to enforcing losses on private creditors is instituted, these conundrums will persist. The German Federal Constitutional Court has helped by insisting that such a dialogue be conducted in order to achieve a more durable political and economic solution. A study of the European Union Court of Justice's Pringle decision (Thomas Pringle $v$ Government of Ireland, Ireland and The Attorney General, Case C-370/12, ECJ, 27 November 2012) suggests that the ECJ will also not rubber-stamp the OMT - and, if it does, the legal victory will not resolve the fundamental dilemmas.

Ashoka Mody (ashoka.mody@bruegel.org): Non-Resident Senior Fellow at Bruegel, and Visiting Professor at the Woodrow Wilson School, Princeton University.

Contributions from, and collaboration with, Will Levine of Union Square Group Capital have greatly enriched this paper. For generous comments, the author is grateful to Kevin Cardiff, Paul de Grauwe, Aerdt Houben, Dan Kelemen, Rosa Lastra, Karl Whelan, Jeromin Zettelmeyer, Guntram B. Wolff and especially to Peter Lindseth. 
As the risk premia on Spanish and Italian bonds soared in the summer of 2012, Mario Draghi, the President of the European Central Bank, promised on 26 July to do "whatever it takes" to restore confidence in the euro area (Draghi, 2012a). In successive announcements in August and September, the Outright Monetary Transactions (OMT) programme was rolled out. Governments benefiting from the programme would be required to step up their fiscal discipline; in return, the ECB would buy their bonds in unlimited quantities to place a ceiling on their interest rates. Markets calmed down, the risks spreads began a steady fall, the lingering crisis abated and a nascent recovery began. Draghi (2013) himself later described the programme as "probably the most successful monetary policy measure undertaken in recent time".

On 14 January 2014, Germany's Federal Constitutional Court (the German Court) made news. It determined that OMT is prima facie incompatible with the Treaty on the Functioning of the European Union (TFEU), the legal basis for the European Union ${ }^{1}$. However, before delivering its final judgment, the German Court chose - for the first time - to seek the opinion of the European Court of Justice [the $E[J]$. The eventual resolution of the questions raised will have wide-ranging implications for the economics and politics of the euro, and for European integration.

ECB action via the OMT was needed because the fiscal options to deal with the crisis had been narrowed down to austerity, which was not paying dividends. European policymakers had determined that they would not - other than in exceptional circumstances - allow euro-area sovereigns to default on their debt to private creditors, although the option of such default was implied in the Treaty's socalled 'no bailout' clauses (Articles 123 and 125). There was, moreover, no political will to compromise national interests in a fiscal union with a sizeable pool of budgetary resources. That placed the entire burden on austerity. While budget trimming would eventually reduce public debt-to-GDP ratios to acceptable levels, markets were losing confidence.

The OMT was politically attractive. The German Chancellor, Angela Merkel, lent it her support even though the Bundesbank President, Jens Weidmann, steadfastly opposed it. For Merkel, who had bought into the ECB's opposition to restructuring privately-held sovereign debt, the OMT was the only way to distance her actions in support of Europe from a sceptical German public.

\footnotetext{
1 The Lisbon Treaty, signed on 13 December 2007, consolidated the texts of the European Union Treaties, the Treaty of the European Union and the Treaty on the Functioning of the European Union. See https://www.gov.uk/government/uploads/system/uploads/attachment data/file/228848/7310.pdf.
} 
The heart of the German Court's case is that the OMT could spread the losses across governments in the euro area. It thus creates a de-facto fiscal union, which is contrary to the political contract. The TFEU authorises a common currency shared among European Union's member states but consciously leaves fiscal sovereignty and responsibility at the national level since the member states have remained unwilling to pay for the mistakes of other member states. The TFEU achieves economic consistency by permitting - arguably encouraging - that the burden of these mistakes be shared by the sovereign's private creditors. But this outlet was closed by a policy decision.

To the supporters of the OMT, the activist German Court is endangering a fragile economic and financial calm, while overstating the limits set by the political contract.

The ECB's position is that the OMT was required mainly to correct distortions in financial markets, which were pricing in unwarranted fears of euro-area exits by stressed countries ${ }^{2}$. Since this market fear blunted the ECB's ability to conduct monetary policy, the OMT was designed to remove the threat of exit and, thereby, improve liquidity to countries under stress. Along with greater fiscal discipline on the part of the distressed sovereign, the OMT would achieve stability without imposing costs on other sovereigns.

The German Court's decision has forced a crucially-important discussion on the state of monetary and fiscal integration in the euro area. Put simply, does the survival of the euro require that the political contract be rewritten? In other words, do member states need to - and are they willing to transparently subordinate their national fiscal interests to help distressed member states? Or, can creative flexibility within the existing framework allow reliance on OMT-like measures that skirt the limits of the TFEU?

The ECJ might seek to appease many parties - as is common in European decisions - and matters might remain confused. However, a clear eventual judgment by the ECJ would have far reaching consequences for the legal and economic basis of the euro area.

Also at stake is the relationship between national constitutional courts and the ECJ. The German Court has often been caricatured as biased against the monetary union and prone to nationalistic decisions.

2 Euro exits fears were, in no small measure, sparked by threats emanating from ECB and other euro-area officials. See 'European Officials as Source of Convertibility Risk', available at http://www.antehoc.com/2012/10/european-officialsas-source-of.html. 
Some have read the latest decision in that light as politically confrontational (Pistor, 2014). However, this reputation and interpretation are ill-deserved. In October 1993, as much of Europe held its breath, the German Court determined that the Bundestag, the German parliament, had the authority to determine Germany's participation in the monetary union as conceived in the Maastricht Treaty. Later when prominent German economists tried to again the stir the Court in a final bid to stop the euro, the judges summarily dismissed their case (Norman, 1998).

In this latest instance, by forcing the discussion, the German Court has done Europe a favour. The Court's uneasiness arises from the culture of quick fixes since the crisis started. An opening has been created for a more durable political and economic solution, necessary for the euro to survive. The issues raised by the German Court should not be viewed as reflecting a Germany-versus-Europe divide. Rather, they raise questions central to the design of the euro area. Specifically, does the TFEU permit a fiscal union? More controversially, can such a fiscal union be implicitly located in the ECB without the political willingness to transparently achieve that elusive goal?

On process, the German Court's deference to the ECJ's opinion could be read as an effort to proactively build a cooperative relationship. The legal scholar and former judge of the German Court, Dieter Grimm, proposed some years ago that when national constitutional courts are concerned that European policies are creating national obligations greater than intended in the Treaty, it is best to ask the ECJ's opinion rather than act unilaterally (Grimm, 1997). This approach makes particular sense since the OMT has not been reviewed or authorised by the Bundestag.

The rest of this paper makes the following arguments. The euro is the common currency of an incomplete monetary union and the OMT was needed to plug the holes that became apparent at the height of the crisis. The German Court is concerned that the OMT blurred the boundary between monetary and fiscal policy defined in the TFEU. The ECJ, based on its so-called 'Pringle decision', will be sympathetic to the philosophy and details spelled out in the German Court's decision. The German Court's position is supported not only by the TFEU but also by a traditional view on the role and limits of central banks as lenders-of-last resort. I conclude by speculating on the prospects and possibilities that lie ahead. 


\section{The OMT in an incomplete monetary union}

On 1 January 1999, the euro became the common currency of an incomplete monetary union. The monetary union remains incomplete because the member countries - having given up independent monetary policy - lack reliable alternative mechanisms for adjustment when under economic stress. Although there are no legal barriers to the movement of people, labour mobility across the countries of the euro area is limited. Since economic adjustment through a moderation in wages is also unreliable, Peter Kenen had proposed in 1969 that a fiscal union is needed to pool budgetary resources for providing relief to countries in distress. An additional problem is that as the central bank of the common currency, the ECB is not clearly authorised to act as a lender-of-last resort to sovereigns [Sims, 2012]; such support is needed when access to market financing is temporarily lost and the sovereign needs to be tided over till confidence is restored.

Despite the fall in the sovereign risk premia prompted by the OMT announcements, the President of the German Bundesbank, Jens Weidmann - also a member of the ECB's Governing Council - openly criticised the programme. On 2 August 2012, when Draghi spoke of possibly unlimited purchases of sovereign bonds under the OMT, he also reported that Weidmann was opposed to the initiative (Draghi, 2012b]. The Bundesbank publicly expressed concerns (Steen, 2012). First, by 'printing' reserves to finance the bond purchases, the ECB would ease the pressure on governments to maintain fiscal discipline. Second, ECB actions might ultimately impose costs on German and other taxpayers if the bonds purchased were not repaid in full.

In contrast to Weidmann, the German Chancellor, Angela Merkel, lent the programme her implicit support. On 7 September, a day after the operational details of the OMT were unveiled, she helpfully noted that the ECB was an independent organisation and the risks to the OMT would be limited since the countries whose bonds were purchased would need to maintain strict fiscal discipline (Wearden, 2012). Merkel was echoing Draghi's themes of enforcing country responsibility ${ }^{3}$.

Despite the German Chancellor's continued support of the OMT, in December 2012, the Bundesbank submitted an extensive critique of the OMT to the German Court ${ }^{4}$. That critique significantly influenced the Court's views.

3 In August and September 2012, Draghi repeatedly insisted on national fiscal discipline: http://www.ecb.europa.eu/press/key/speaker/pres/html/index.en.html.

4 The English translation of the Bundesbank submission to the German Court is available at: http://www.antehoc.com/2013/06/bundesbank-letter-to-german.html. 
The future of the OMT is so important because even as it eased market fears, it exposed key fault lines in the architecture of the euro. In creating a temporary fix for the incompleteness of the euro-area monetary union, the OMT blurred the line between monetary and fiscal policy. As the Bundesbank correctly stated in its submission to the German Court, the European monetary union was created as "... a community of countries which have assigned responsibility for monetary policy over to the supranational level, but which continue to decide on fiscal and economic policy primarily at a national level, and which deliberately did not enter into a liability or transfer union ${ }^{, 5}$. This structure was embodied especially in Articles 123 and 125 of the TFEU.

The legal and economic question of interest is whether the OMT tried to bypass the intent of the Treaty by creating a de-facto fiscal union (a liability or transfer union in Bundesbank terminology). If so, without their explicit authorisation, countries had become fiscally responsible for the mistakes of other member countries.

\section{The boundaries of monetary and fiscal policy in the euro area}

The TFEU requires that the ECB must not 'print' money to finance the government. This is the so-called 'monetary financing' concern. In particular, the ECB must not finance a specific government and, in the process, impose an eventual financial obligation on the taxpayers of another government. The Treaty's intent is to prohibit one member state from 'bailing out' another member state and, thereby, enforce national responsibility of fiscal affairs.

The German Court's position is straightforward. The ECB's mandate is to conduct monetary policy for the common currency area. However, the OMT would operate by selectively lowering interest rates for particular countries. The OMT's focus on support for a particular country is not incidental - it is integral to the OMT. ECB financial capacity is intended to leverage lending to the distressed member state by the European Stability Mechanism (the ESM) under condition of prudent fiscal behaviour. For this reason, the German Court's position is that OMT is not an instrument of monetary policy. Instead, it pursues economic policy in the interest of a particular member state and, hence, "manifestly violates" the distribution of authority between the central bank and member states. As such, it goes beyond the

5 The English translation is available at: $\mathrm{http}: / / w w w . a n t e h o c . c o m / 2013 / 06 /$ bundesbank-letter-to-german.html. 
authority accorded to the ECB under Articles 119 and 127 of the TFEU. In addition, the OMT circumvents Article 123 of the TFEU, which prohibits the monetary financing and bailout of governments by the ECB.

A widely-held presumption is that the ECJ, since it leans towards 'more Europe', will rule in favour of the OMT, possibly with some inconsequential restrictions to appease the German Court. However, there may be rather more common ground between the German Court and the ECJ than is generally presumed. The ECJ's Pringle decision (ECJ, 2012) - which confirmed the legal standing of the European Stability Mechanism (the ESM] - suggests that the ECJ will be predisposed to support the German Court's interpretation of the OMT. The ECJ's room for manoeuvre will be limited by the positions it has taken on Articles 123 and 125 of the TFEU, which enshrine the fiscal sovereignty of the member state.

The ESM was an intergovernmental agreement - and did not involve the ECB. As such, the issue at hand was Article 125, the 'no-bailout' clause that prohibits a member state from taking on the financial obligations of another member state. In July 2012, Irish parliamentarian, Thomas Pringle, claimed before the Irish Supreme Court that the ESM violated this provision. The Supreme Court referred the matter to the ECJ. In November 2012, the ECJ determined that the ESM did not violate Article 125. In doing so, the ECJ allowed rather more scope for bailout than had been generally presumed, but arguably that was appropriate in a critical phase of the crisis. The German Court similarly acted in sympathy with the policy objectives of the ESM. That makes the German Court's concerns on the OMT particularly significant.

By finding space between Articles 122 and 123 of the Treaty (paragraphs 131 and 132 of the judgment), the ECJ arrived at a creative interpretation of Article 125 to validate the ESM (Craig, 2013). But that very creativity implied clear restraints on the ECB. In essence, the ECJ found latitude in the Treaty for governments - responsible to their own taxpayers - to assist other governments. But the ECB, as the independent central bank, has no such leeway. Moreover, the German Court's argument implies that the OMT's reach transcends even the latitude within which the ESM operates.

Article 122 allows for the possibility that the European Union or a member state may provide financial support to another member state facing exceptional circumstances beyond its control. In May 2010, the European Financial Stability Mechanism [the EFSM] was established on the basis of Article 122. However, because 'exceptional' circumstances could not be invoked readily for a permanent body 
such as the ESM, and because it was not straightforward to claim that problems on account of excessive sovereign debt were beyond the member's control, Article 122 was not used directly to establish the ESM (de Witte, 2013). Instead, the ECJ used it mainly to note that Article 125 could not have prohibited financial assistance of any sort because then Article 122 would have been inconsistent with the Treaty (paragraph 131).

To define the space for the ESM, the ECJ also highlighted that Article 123 of the TFEU creates a stricter prohibition on the ECB, denying it any form of lending [ "overdraft or any other type of credit facility"] in favour of member states. Specifically, the ECJ found that the ESM could do what the ECB could not. Thus the ECJ allowed for latitude in governmental action authorised by national parliaments. But it insisted that the ECB is still bound by the limits set in the TFEU.

Thus, although not called on to comment on Article 123, the ECJ did so to highlight the difference between the ECB and the ESM. Importantly then for the OMT, just as the ECJ opened the door for the ESM, it went out of its way to warn that, under Article 123, the ECB is barred from similar action. Presumably, when financial assistance to a specific member state becomes necessary, it must be a political decision since it implies a fiscal action.

The ECJ's reasoning in the Pringle decision is consistent with the German Court's concern that the OMT blurs the distinction between common monetary and national fiscal policy.

Moreover, the ECJ identified limits on the ESM, which place further question marks on the scope for OMT. Article 125 allows for "financial assistance" but prohibits the Union or a member state from taking on the commitments of another member state. "Financial assistance" can take the form of a loan [ "credit line"] to a distressed member state provided it is repaid over time with "an appropriate margin" (paragraph 139). The fine distinction, presumably, is that financial assistance is to be repaid, but if commitments are assumed, the distressed member state is relieved of the burden of honouring its obligations. Thus, even if the OMT were to jump the hurdle set by Article 123, it would need to be deemed "financial assistance" rather than the assumption of a government's obligations and, hence, a 'bailout'. Importantly, the definition of 'no bailout' requires that the member state being assisted pays an "appropriate margin".

Supporters of the OMT contend that it is a monetary policy tool. It would be triggered under 
extraordinary circumstances when the market's risk assessments are distorted by an unwarranted 'fear' that a member state might leave the euro. Assistance under the OMT would be provided by helping the distressed member state regain market access at interest rates that are more in line with its economic fundamentals. This task is rightfully undertaken by the ECB because returning markets to normal functioning is essential for the conduct of euro-area monetary policy.

While the Bundesbank took the strong position that the ECB should not be in the business of guaranteeing that a member state remains in the euro area, the basic contention of the German Court a contention that finds support in the ECJ's Pringle decision - is that a fiscal union cannot be created by the backdoor. That is a political decision and must occur through a change of the Treaty and not through its creative reinterpretation. Specifically, the German Court asked:

- Whether the "fear factor" alleged to cause an "undue" rise in sovereign spreads could be differentiated from a real threat of insolvency;

- Whether the OMT's offer to buy "unlimited" amounts of sovereign debt implied assuming the debt repayment obligations of the distressed government; and, moreover, whether the ECB's commitment to be pari passu with private lenders - ie in the event of a default, being repaid on the same terms as private lenders - created additional risk that the ECB, and, by extension, to other sovereigns would incur losses.

The next two sections elaborate on these concerns expressed by the German Court and argue that the ECJ will likely concur with them.

\section{The fear factor and monetary transmission}

The German Court sums up the ECB's position on the OMT in this way:

"[The ECB's] monetary policy is no longer appropriately implemented in the Member States of the euro currency area because the so-called monetary policy transmission mechanism is disrupted. In particular, the link between the key interest rate and the bank interest rates is impaired. Unfounded fears of investors with regard to the reversibility of the euro have resulted in unjustified interest 
spreads. The Outright Monetary Transactions were intended to neutralise these spreads."

But the German Court was unconvinced by this argument. Citing the Bundesbank and other experts, the German Court's assessment reads: "... such interest rate spreads only reflect the scepticism of market participants that individual Member States will show sufficient budgetary discipline to stay permanently solvent. ... one cannot in practice divide interest rate spreads into a rational and an irrational part..."

The key empirical and analytical question, therefore, is whether the spreads can be decomposed into components representing 'fear of disruption' and 'country credit risk'. The ECB's evidence on this has been less than persuasive. For example, in a September 2012 speech justifying the OMT, President Draghi chose a persistent outlier to make his point (Draghi, 2012c). He referred to rates on Spanish mortgages in the 5-10 year maturity range as having a larger risk premium than comparable German mortgages. However, an examination of that evidence shows that "both longer and shorter maturities had much lower rate differences than did his chosen category. Strikingly, the chosen maturity category has de minimis volume in Spain". This example is all the more curious because the OMT intends to target sovereign debt at maturities of $1-3$ years; the link from there to mortgages of $5-10$ years is a tenuous one.

The scholarly evidence for market sentiments as drivers of risk premia is also unpersuasive. It is commonly stated that markets were unduly optimistic before the crisis and became excessively pessimistic towards the end of 2010 (for example, de Grauwe and Ji, 2012). But the roller-coaster movements in euro-area sovereign spreads are better explained by incoherent policy. Before the crisis, markets did not believe the threat that losses would be imposed on private creditors - and, hence, the Irish paid lower risk spreads than the Germans in 2007. After the crisis started, the countries receiving official assistance came under particularly severe market pressure because privately-held debt was now subordinated to the senior, official debt. The rise in spreads between late 2010 and mid-2011 is almost entirely explained by the subordination of private debt (Steinkamp and Westerman, 2013, and Mody, 2014]. The fall in spreads, thereafter, is explained by the policy steps to subordinate official to private debt. In July 2011, the terms of official lending to the assisted countries were eased, sending a signal that official creditors will bear the initial burden of further sovereign distress. When that proved insufficient for Italy and Spain, the OMT was needed in the second half of

6 'Convertibility Risk - Cherry Picking* Interest Rate Spreads', 2012, available at: http://www.antehoc.com/2012/10/convertibility-risk-cherry-picking.html. 
2012 to spread the Europhoria (Mody, 2014).

The German Court goes on to argue that an ill-conceived attempt to make a distinction between a country's real solvency risk and the market's ill-founded fear and to act on that basis to lower the risk premia runs the risk of violating the core intent of the TFEU - and, in doing so, it invokes the ECJ's Pringle decision:

"... the existence of such [risk] spreads is entirely intended. As the Court of Justice of the European Union has pointed out in its Pringle decision, they are an expression of the independence of national budgets, which relies on market incentives and cannot be lowered by bond purchases by central banks without suspending this independence".

In his submission to the German Court, former ECB Executive Board member, Jorg Asmussen, conceded that the OMT was not just trying to dampen the 'fear factor' (Asmussen, 2013). The two-fold objective of the OMT programme, he said, is "protecting the market mechanism so as to urge the Member States to make the necessary reforms". But if this is so - and since the OMT is to act in concert with ESM lending - the German Court and the ECJ are not so far apart. The German Court is concerned that rather than conducting 'monetary' policy, the ECB is also engaging in 'economic' policy - urging member states to undertake reforms, in Asmussen's terms.

There is, moreover, an operational problem. Even assuming that a 'fear' factor exists, its size and significance will depend on the country's creditworthiness. Hence, in each instance, the ECB will be required to make a judgment. No simple rule, such as a transparent threshold, is possible. The ECB will, therefore, be necessarily drawn into making country-specific judgments and decisions.

That, of course, is the antithesis of what the central bank should be doing. Especially because the OMT cannot be triggered unless a country asks for ESM support, governments and their creditors could pursue an unsustainable strategy until it is too late. At that point, the ECB will inevitably be sucked into political judgments. 


\section{No bailout}

The ECB contends that by only purchasing bonds on the secondary market, it is neither extending credit nor is it influencing the market pricing mechanism, and, it is, therefore, not assuming a sovereign commitment. But the German Court is only stating the obvious when it notes that even if the ECB allows some time distance from the sovereign's primary bond issue, the OMT "encourage[s] third parties to purchase the government bonds at issue on the primary market by providing the prospect of assuming the risk associated with the acquisition". In other words, the German Court is saying that the OMT is either providing credit or a free 'put option' to investors. That interpretation leads to a violation of Article 123. It is hard to see how the ECJ could conclude otherwise.

In his submission, Asmussen acknowledged the limits set by Article 123:

"Article 123 of the Treaty prohibits monetary financing. In particular, we are not allowed to buy any government bonds directly, i.e. on the primary market. Government bonds can only be purchased if they are already on the market and traded freely".

But he did not clarify how the limits set by Article 123 would be honoured. The OMT was also sold as an 'unlimited' programme - the 'whatever it takes' bazooka. Along with being pari passu with creditors (discussed below), the promise of unlimited purchases helped calm markets. Once again, Asmussen reflected this tension in his submission.

"No ex ante quantitative limits are set on the size of Outright Monetary Transactions. ...we announced that our OMT interventions would be ex ante 'unlimited.' We have no doubt that this strong signal was required in order to convince market participants of our seriousness and decisiveness in pursuing the objective of price stability. At the same time, however, the design of OMTs makes it clear to everyone that the programme is effectively limited, for one by the restriction to the shorter part of the yield curve and the resulting limited pool of bonds which may actually be purchased".

Perhaps, unlimited purchases at the short-end are sufficient to eliminate the so-called 'redenomination' risk - the risk that the euro could break up. The German Court is concerned: 
"The 'factual' limitation of the volume of bond purchases by the amount of the government bonds issued already in the currently scheduled maturity spectrum of one to three years highlighted by the European Central Bank in the proceedings before the Federal Constitutional Court - is not likely to sufficiently ensure an adequate quantitative limitation. By changing their refinancing policies, the Member States that benefit can increase the volume of government bonds that are currently covered by the OMT Decision; it is unclear what would follow from the European Central Bank's intention to observe the emission behaviour of individual Member States".

To this, the ECB response has been that the conditionality that accompanies the ESM programme could require that countries continue to issue longer maturity bonds. In addition, it will monitor countries subject to the OMT to ensure that they don't begin issuing all of their new debt in the OMT-eligible 1-3 year maturity bucket (Cotterill, 2012).

Thus, at least implicitly, the ECB recognises that 'unlimited purchases' violate Article 123 but limited purchases dilute the value of the programme. Moreover, once again, the intent of monitoring a country's debt issuance strategy exposes the ECB to political terrain.

But, perhaps, the most important German Court concern is the risk of default on the ECB's holdings acquired under OMT. This could be rephrased in the ECJ's Pringle terminology to ask whether the ECB is being compensated with an appropriate margin.

Recall that in its expansive interpretation of Article 125, the ECJ, while determining that loans made by the ESM are consistent with the TFEU, required that the loan pay an adequate return to the lender. The ECJ was clear that the ESM Treaty "in no way implies that the ESM will assume the debts of the recipient Member State" (paragraph 139). The ECJ notion of return to the lender was a narrow one: it did not include the benefits achieved by providing systemic financial stability and resilience. Indeed, it reaffirmed the conventional TFEU interpretation that the goal of financial stability is to be achieved by the member states maintaining the needed fiscal discipline for honouring their debts. For this reason, if a particular OMT transaction were to face losses, it could not be legitimised on the basis of financial stability or a similarly broad dividend to the Union.

By accepting losses on account of a particular sovereign, the ECB would be imposing a fiscal burden on 
the other member states - without the necessary political authorisation. In a country with a single fiscal authority, the central bank has recourse to fiscal support in the event of a loss. With multiple fiscal authorities, the authors of the TFEU were rightly concerned that such recourse would create incentives for fiscal indiscipline.

In a recent, much-read, position, Paul De Grauwe (2014) claimed that a central bank cannot incur losses. Were a sovereign to default on its obligations to the ECB, the member states would recapitalise the ECB by lending it money. Over time, the ECB would pay interest to the member states for that loaned money. This process, De Grauwe asserts, is costless to all parties?

But, of course, the interest that the ECB pays to the member states would come from its profits. Thus, those profits would have been used, in effect, to pay for the losses incurred by the ECB. In so doing, the ECB would have acted to favour a particular sovereign, and thereby would have created a fiscal transfer mechanism. That transfer would be particularly costly if the assisted member state eventually left the euro area ${ }^{8}$.

This matter is aggravated by the pari passu feature of the OMT. The ECB's holdings of Greek debt acquired earlier under its Securities Markets Programme (SMP), starting May 2010, were effectively granted senior status to private creditors. When Greek debt was restructured in March 2012, the ECB exchanged its holdings for bonds that were not subject to the losses imposed on private creditors (Black, 2012). Thus, the ECB remained whole.

However, since ECB seniority under SMP increased the losses borne by bondholders whose securities were not purchased by the ECB, the SMP was not popular in the market. For this reason, to further reassure market investors, the seniority claim was apparently relinquished under the OMT. In the OMT press release, the ECB said: "The Eurosystem intends to clarify in the legal act concerning Outright Monetary Transactions that it accepts the same (pari passu) treatment as private or other creditors with respect to bonds issued by euro area countries and purchased by the Eurosystem through Outright Monetary Transactions, in accordance with the terms of such bonds".

\footnotetext{
? The process of calling capital from the member countries is, moreover, far from straightforward. For instance, a vote on loss-sharing is required, not to mention the obstacles to sharing losses in the event of an exit from the euro. See 'Loss Sharing in the Eurosystem - excluding Target2 Losses', available at http://www.antehoc.com/2013/03/eurosystemloss-sharing-in-monetary.html - more.

8 These same problems arise also in the context of ECB exposure to banks that are insolvent, and for the same reason insufficient clarity on the policy and willingness to institute losses on private creditors. This may change, but the extent to which it will remains unclear.
} 
Note, therefore, in highlighting its pari passu status, the ECB recognised that it was moving beyond the central banking domain of managing liquidity disruptions into space were insolvency to become a real market concern.

The German Court has concluded that such equal treatment in creditor status probably renders the OMT unconstitutional. Their interpretation of Article 123 of the TFEU is that "the possibility of a debt cut must be excluded". Thus, the court is concerned not with the seniority issue per se but by the possibility that the ECB will not be repaid in full, in which case, the ECB would have acted to bailout the sovereign creditor in contravention to Articles 123 and 125.

It is possible that the ECJ may invoke a broader community goal in validating the OMT. But that would be a departure both from how the OMT has been sold and how the TFEU has so far been interpreted. It would imply an interpretation that the TFEU permits a fiscal union.

\section{The economic analysis of the lender of last resort}

The ECJ will also need to contend with well-established central banking practices, which are implicit in the German Court's reasoning. A central bank must address systemic liquidity risk arising from shortterm financial disruption; it should not address solvency problems that are at the heart of the OMT's design.

The legal analysis, therefore, parallels an economic logic. At its centre is the distinction between liquidity and solvency. Temporary market disruption leads to short-term funding requirements that are met through liquidity provision by the central bank acting in its capacity as a lender of last resort. The risk of sovereign insolvency, however, is a fiscal problem. This is never an easy distinction to make in practice, requiring a presumption one way or another.

Is the OMT intended to solve a solvency or liquidity problem? The way it is designed, the solvency concern looms large and, at best, the solvency and liquidity threats are rolled into one. The OMT is to be triggered precisely when a member state faces a real threat of insolvency; the market merely amplifies that threat into a broader financial panic. A central bank's liquidity operation in such a situation places 
it in an untenable position.

The strong preference of private creditors that they receive same treatment as the ECB in the event of a default, and discussion of the financial options in that event, reflect the concern that the OMT is designed for conditions in which a default risk is non-trivial. The German Court's reservations on these matters mirror those voiced by central banking experts (Capie, 2002).

The situation is clearly aggravated in the euro area since, were there to be insolvency, the losses would be distributed among member states whose governments and taxpayers were not party to the decisions made. A central bank's role as a lender of last resort also requires that it not undertake operations primarily to assist specific entities in distress (Capie, 2002), because that creates the socalled 'moral hazard' risk that lenders will lend with reckless abandon in the knowledge that they will be protected. Thus, Sims (2012, p. 221] notes:

"... with the expanded balance sheets of the central banks, returns on their assets will no longer necessarily move in parallel to the rate on reserve deposits. In the case of the ECB, sovereign debt assets could default. For both these reasons, future monetary tightening could require the central bank to ask for a capital injection from the treasury. For the ECB, there is no one treasury to respond. There is a formal "capital key," a set of proportions according to which countries of the euro zone are required to share in providing capital to the ECB when needed. But if this were required, Germany would bear a large part of the burden, and it would be clear that German financial resources were being used to compensate for ECB losses on other countries'sovereign debts".

Once again, the German Court's concerns with 'selectivity' have echoes in the central banking literature. A thought experiment helps clarify the salience of the selectivity issue in an incomplete monetary union. Should the ECB tailor its policy rates to a particular member state? During the boom years, should interest rates have been raised to dampen the real estate booms in Ireland and Spain? The argument can be made that the failure to do so had systemic consequences. Or consider Italy today. The OMT is a promise to place a floor on the price of Italian bonds. If that falls within the authority of the ECB, then should the ECB have pursued more aggressive reduction of its policy interest rate early on to pre-empt deflationary conditions in the weakest economies; and should it not have long since being pursuing unconventional methods to prevent Italian deflation? Deflation can be at least as 
serious a risk to debt dynamics as excessively high interest rates. Fiscal austerity in a deflationary condition can be debilitating.

Because the member states chose to move ahead with a monetary union without a fiscal union to backstop such eventualities, the TFEU is based on the promise of fiscal discipline by each member state to prevent such risks from arising in the first place. Where the presumed discipline proves insufficient, the TFEU's intention - expressed in Article 125 - is that the country would not repay its private creditors. The effort today is to square a circle: sovereigns must repay private creditors (barring exceptional circumstances] but without the pooled resources of a fiscal union. The OMT steps into that breach.

\section{Prospects and possibilities}

The German Court has challenged the OMT on the basis of its congruence with European law. In the end, the German Court may, indeed, restrain Germany from cooperating with the OMT because it implies obligations that are not permitted by the German constitution. But for now, the task is very much on how to interpret the TFEU.

The ECJ may be less fussy than the German Court in determining the circumstances under which the OMT could be triggered. The ECB may then be able to use that flexibility and not hang its OMT trigger on the fuzzy 'fear factor'. But a general state of financial instability, which creates a legitimate role for a central bank, does not imply support for a particular member state. That the ECB, nevertheless, has chosen to link the OMT to conditional lending by the ESM suggests that the ECB is aware that the OMT is not a proper lender-of-last resort function. It bridges into lending to sovereigns facing solvency risk.

If so, the ECJ is very clear. It has interpreted Article 123 as strictly prohibiting any lending to a sovereign by the ECB. There appear no exceptions to fall back on for breathing new life into Article 123. This is all the more so since the economic conditions under which the OMT is to be operational are more dire than those stipulated for the ESM and, as such, might not even meet the standards of Article 125. The ESM was given the green light by the ECJ on the basis that the support would be through a loan that would be paid back with an appropriate return. In the case of the OMT, the support is to be provided when the ESM has proved insufficient and the conditions expressly raise the prospect of a 
loss to be borne by the ECB's balance sheet and its shareholders. It, therefore, directly violates the 'nobailout' intent of Article 125. Moreover, it does so by lowering the interest rate paid by the sovereign and, hence, raises the concern that market discipline is being diluted.

The problem is a simple one. The authors of the TFEU wrote a document that was consistent with the vision of the euro as an incomplete monetary union. That construct was intended to work on the basis of fiscal discipline by countries accompanied by default on debt held by private creditors where the discipline proved insufficient. The threat of the default was intended to focus the minds of both the lenders and the borrowers. Decision makers today have concluded that default is too costly but the alternative of completing the monetary union through a fiscal union is not politically feasible.

The fact that the OMT was successful in dampening market concerns is testament to the need for a fiscal union. It also is an indication of the size of such centralised fiscal resources that would be a credible bulwark against market speculation.

A democratically-validated, political path to a fiscal union has proven to be a receding target. This should not have been a surprise to those who have observed the evolution of the euro. The OMT, in effect, offers an apparently elegant technocratic solution to the euro-area's fiscal union conundrum.

In highlighting the tensions between the TFEU and the OMT, the German Court is basically concerned that the OMT is a fiscal union by the backdoor. The ECJ could validate the current design of the OMT locating the fiscal union in the central bank - in which case, the nature of the euro area will be fundamentally altered and the ECB will become a more political institution. Alternatively, if the ECJ were to determine that the German Court's concerns need to be addressed by changes to the OMT - by imposing serious limits on purchases of sovereign bonds and requiring the ECB to claim seniority to private creditors - the OMT will be rendered ineffective.

There is a third option. And that would be to agree that the OMT is needed as temporary support because an incomplete monetary union creates intolerable risks. The ECJ would ask the political actors to meet their responsibility by providing a transparent and legitimate mandate for a permanent OMT. They would do so by jointly guaranteeing the ECB against losses incurred if a particular transaction ends in a default. That guarantee may never be needed. But it would focus the minds and clarify who bears the cost. Then Europe would have taken a real step forward. 


\section{References}

Asmussen, Jörg (2013) 'Introductory Statement by the ECB in the Proceedings before the Federal Constitutional Court', available at: http://www.bis.org/review/r130612a.pdf, 11 June

Black, Jeff (2012) 'ECB Is Said to Swap Greek Bonds for New Debt to Avoid Any Enforced Losses', retrieved from http://www.bloomberg.com/news/2012-02-16/ecb-said-to-swap-greek-bonds-fornew-debt-to-avoid-loss-from-restructuring.html, 17 February

Capie, Forrest (2002) 'Can there be an International Lender-of-Last-Resort?' International Finance 1[2]: $311-325$

Cotterill, Joseph [2012] 'The OMT and "limits"', Financial Times Alphaville, available at: http://ftalphaville.ft.com/2012/09/18/1166021/omt-buyers-remorse, 18 September

Craig, Paul (2013) 'Pringle: Legal Reasoning, Text, Purpose and Teleology', Maastricht Journal of European and Comparative Law20 (1): 3-11

De Grauwe, Paul (2014) 'Why the European Court of Justice should reject the German Constitutional Court's ruling on Outright Monetary Transactions', available at http://blogs.Ise.ac.uk/europpblog/2014/03/04/why-the-european-court-of-justice-should-rejectthe-german-constitutional-courts-ruling-on-outright-monetary-transactions/

De Grauwe, Paul and Yuemei Ji (2012) 'Mispricing of Sovereign Risk and Multiple Equilibria in the Eurozone', Journal of Common Market Studies 50(6): 866-880

De Witte, Bruno (2013) 'Using International Law in the Euro Crisis', Centre for European Studies, University of Oslo, Working Paper4

Draghi, Mario (2012a) 'Verbatim of the Remarks made by Mario Draghi', Global Investment Conference in London, 26 July, http://www.ecb.europa.eu/press/key/date/2012/html/sp120726.en.html

Draghi, Mario (2012b) 'Introductory statement to the press conference (with $Q \& A$ )', Frankfurt am Main, 2 August, http://www.ecb.europa.eu/press/pressconf/2012/html/is120802.en.html\#qa

Draghi, Mario (2012c) 'Building the Bridge to a Stable European Economy', The Federation of German Industries, Berlin, 25 September, http://www.ecb.europa.eu/press/key/date/2012/html/sp120925.en.html

Draghi, Mario (2013) 'Questions and Answers at Press Conference', 6 June, Frankfurt am Main, http://www.ecb.europa.eu/press/pressconf/2013/html/is130606.en.html

European Central Bank (2012) 'The OMT Press Release', available at http://www.ecb.europa.eu/press/pr/date/2012/html/pr120906 1.en.html 
European Court of Justice (2012) 'Judgment of the Court (Full Court): Thomas Pringle v Government of Ireland and The Attorney General', available at http://curia.europa.eu/juris/liste.jsf?num=C-370/12, 27 November

Federal Constitutional Court (2014) 'Principal Proceedings ESM/ECB: Pronouncement of the Judgment and Referral for a Preliminary Ruling to the Court of Justice of the European Union', judgment: http://www.bverfg.de/entscheidungen/rs20140114_2bvr272813en.html; press release: http://www.bundesverfassungsgericht.de/en/press/bvg14-009en.html

Grimm, Dieter [1997) 'The European Court of Justice and National Courts: the German Constitutional Perspective after the Maastricht Decision', Columbia Journal of European Law 3: 229-242

Kenen, Peter (1969) 'The Theory of Optimum Currency Areas: An Eclectic View', in Robert Mundell and Alexander Swoboda (eds) Monetary Problems of the International Economy, Chicago: University of Chicago Press

Mody, Ashoka (2014] 'Europhoria, Once Again', http://www.bruegel.org/nc/blog/detail/article/1242europhoria-once-again/

Norman, Peter (1998) 'German Court Rejects Emu Challenge', Financial Times, 3 April

Pistor, Katharina (2014] 'German Court decision: Legal authority and deep power implications', available at http://www.voxeu.org/article/german-court-decision-legal-authority-and-deep-powerimplications

Steen, Michael (2012) 'Weidmann isolated as ECB Plan Approved', Financial Times, 6 September

Steinkamp, Sven and Frank Westermann (2014) 'The Role of Creditor Seniority in Europe's Sovereign Debt Crisis', forthcoming in Economic Policy, 29(79): July

Wearden, Graham (2012) 'Eurozone crisis live: Merkel backs ECB rescue plan as markets remain cheerful - as it happened', The Guardian, http://www.theguardian.com/business/2012/sep/07/eurozone-crisis-ecb-plan-euro-omt - block504a0af058f94f441baa?74d, 12 September 